\title{
Review
}

\section{A Basic Approach to Lymph Node and Flow Cytometry Fine-Needle Cytology}

\author{
Helena Barroca ${ }^{a}$ Cristina Marques $^{b}$

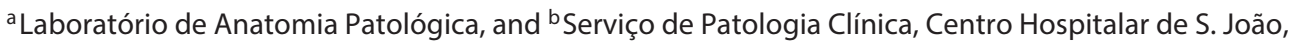 \\ Porto, Portugal
}

\section{Key Words}

Flow cytometry · Cytology · Lymph node - Lymphoma .

Fine needle biopsy

\begin{abstract}
According to the World Health Organization (WHO), the new classification of lymphomas is mainly based on morphological, immunophenotypical, and molecular criteria. Consequently, this new approach has led from the substantial role that architecture played in the past to a secondary panel highlighting the role of fine-needle biopsy (FNB). Applied together with other ancillary techniques, such as flow cytometry $(F C)$, FNB is a potential tool for the diagnosis of lymphomas, and enlarged lymph nodes represent an excellent target for the implementation of this technique. Despite the difficulties inherent in this technology, which might pose problems in differential diagnosis, in the majority of cases this joint work allows an accurate diagnosis of malignancy and even correct subcharacterization in routine lymphomas. Additionally, in selected cases, other molecular techniques like FISH and PCR can also be performed on FNB specimens, helping in the characterization and diagnosis of lymphomas. In this review, we discuss the basic aspects of the combination of FNB cytology and FC in the diagnosis and subclassifi-
\end{abstract}

cation of lymphomas. The preanalytical phase is extensively discussed. The advantages, disadvantages, and technical limitations of this joint work are addressed in general and in terms of the accurate subclassification of lymphomas.

(c) 2016 S. Karger AG, Basel

\section{Introduction}

The new classification of lymphomas of the World Health Organization (WHO) classification of tumors of hematopoietic and lymphoid tissue is based on morphological criteria, immunophenotype, and molecular characteristics of lymphoid cells in the appropriate clinical setting [1]. As a consequence of this, the substantial role that architecture played in the past in the classification of lymphomas has become, following the above mentioned approach, secondary in the majority of routine lymphoma diagnoses.

This new approach to the diagnosis of lymphomas highlights the enormous diagnostic potential that fineneedle biopsy (FNB) cytology has when applied together with other ancillary diagnostic techniques, such as immunocytochemistry, flow cytometry (FC), cytogenetics, and molecular techniques (FISH, CISH, and PCR), which

\section{KARGER}

E-Mail karger@karger.com www.karger.com/acy
(C) 2016 S. Karger AG, Basel

0001-5547/16/0604-0284\$39.50/0
Correspondence to: Dr. Helena Barroca

Laboratório de Anatomia Patológica, Centro Hospitalar de S. João Al. Hernani Monteiro

PT-4200-451 Porto (Portugal)

E-Mail hbarroca@gmail.com 
nowadays are accessible to most laboratories $[2,3]$. Furthermore, in the majority of cases, lymphadenopathies are benign/reactive and, among those that have a diagnosis of lymphoma, B-cell lymphomas represent $90 \%$ of the non-Hodgkin lymphomas. Of the latter, more than half are diffuse large B-cell lymphomas (DLBCL) or follicular lymphomas (FL) (50 and 20\%, respectively) [4]. All of these facts highlight the huge potential of FNB and FC together as diagnostic tools for the primary assessment of lymph nodes.

FNB is a simple procedure in which a needle is inserted into a site and a small amount of tissue is sucked out to provide a sample of cells for laboratory analysis. When performed by trained operators and for the correct indications, this is one of the safest and most minimally invasive, cost-effective, and accurate diagnostic techniques.

FNB has the following advantages over other techniques, histology: (1) it achieves quicker results, (2) it is better tolerated by the patient, (3) through rapid on-site evaluation (ROSE) it allows triaging and selection of material for other ancillary tests and ensures that the needle is inserted into a lymph node, (4) it provides a better cytomorphology and better rinsing for FC and molecular biology, and (5) it is less expensive.

Enlarged lymph nodes represent an excellent target for the implementation of this technique for the diagnosis of both benign and malign lymphadenopathies.

Despite the numerous publications on this subject stressing the enhancement of FNB and FC sensibility and specificity as a first-approach technique for the diagnosis of enlarged lymph nodes and lymphoma [5-7], the prevailing assumption is still that FNB should only be used in cases in which an excisional biopsy is medically contraindicated, in follow-up, in relapses of previously characterized lymphomas, or to rule out metastatic and reactive causes. In most guidelines of lymphoma protocols, histology is still considered the gold standard for the morphological diagnosis of lymphoma $[5,8,9]$.

The main arguments against the use of FNB for lymphoma diagnosis insist on the fact that FNB does not provide an architecture assessment, precluding accurate subclassification or grading in some lymphoma subtypes. As an example, there is often a reference to the impossibility of properly grading FL by FNB. FL is graded from 1 to 3 based on the number of centroblasts per high-power field $(\times 40)$ in 10 representative neoplastic follicles. Differentiation between low grade (grades 1-2) and high grade (grade 3) is important not only for the prediction of tumor behavior but also for therapeutic decisions [1]. The aforementioned criteria do not prevent the diagnosis of

FC Fine-Needle Cytology in Lymph Nodes
FL by FNB but can in some cases limit accurate characterization and determine, in a second step, the need for histology. The loss of architecture is also pointed out as an obstacle in the identification of the more recently emerging diagnosis of in situ follicular neoplasia and in situ mantle cell lymphoma (MCL). Another argument against FNB is the need to store material for upcoming molecular studies with the aim of identifying new biological markers for diagnosis or for new therapeutic options.

FC is an ancillary technique that can be easily coupled with the FNB technique, allowing a more accurate and reliable determination of the immunophenotype of lymphoid populations. Immunophenotyping by FC is nowadays recognized for its capacity to distinguish abnormal populations from reactive ones, allowing objective classification and quantification of the cells. The ability to perform a complete basic phenotype in limited cytology specimens makes it the ideal technique for combined application with FNB in the diagnosis of lymphoma.

FC has the ability to be operational in small samples, and it has some important advantages over immunohistochemical stains. Multiple phenotypic and 2 physical (size and complexity) parameters of individual cells can be simultaneously assessed to identify both major and minor abnormal populations. FC has the capacity to evaluate multiple parameters in a single cell, such as coexpression of CD5 and CD23 in chronic lymphocytic lymphoma (CLL). FC remains the best way to identify surface immunoglobulins and evaluate monoclonality in lymphoid B-cell populations by analyzing the immunoglobulin $\kappa$ and $\lambda$ chain ratio. FC is also able to evaluate the mean fluorescence intensity (MFI) of antigen markers, which can have diagnostic implications, as is the case of CD20 and surface immunoglobulin low-intensity, which characterizes CLL. FC also facilitates the identification of aberrant T-cell phenotypes, helping in the cytological diagnosis of T-cell lymphomas. FC is also crucial for the identification of minor populations of neoplastic cells on a background of reactive lymphocyte populations, in a partly involved lymph node by lymphoma, that otherwise would go undetected by immunohistochemistry (IHC). Recently, the possibility of detecting T-cell clonality with the aid of a broad panel of antibodies against the variable region of the TCR $\beta$ gene was reported [10, 11].

Beyond the pros and cons previously mentioned regarding $\mathrm{FNB} / \mathrm{FC}$, this tandem approach has limitations that have been pointed out and should always be taken into account. FNB requires an experienced operator and 
in many hospitals there is a limited availability of cytopathologists. Another problem is the availability of ancillary tests in many departments. FNB of lymph nodes should be carried out with ROSE in order to evaluate the adequacy of the collected material and to perform a proper specimen triage. This procedure is time consuming and requires commitment of the professionals.

Conversely, false-negative results can be due to error or inadequate sampling, i.e. in lesions with marked fibrosis, extensive necrosis, or partial involvement of the lymph nodes. These limitations can be avoided by doing multiple passes and ensuring sampling of different areas of the node. Errors can occur in the interpretation of the smears, as well as in the interpretation of FC results. Errors can, furthermore, be due to sample representation or paucity of diagnostic cells such as Reed-Sternberg cells in Hodgkin lymphoma (HL). Attempts to diagnose HL in FC have long been unsuccessful, and there is still no consens essentially due to the lack of specific markers. Recently, some authors have demonstrated that Reed-Sternberg cells can be detected by FC and that classical HL (cHL) can be diagnosed by FC with a high sensitivity (88.7\%) and specificity (100\%), and it can be distinguished from other putative differential diagnosis like T-cell-rich large B-cell lymphoma and anaplastic lymphoma $[12,13]$.

Difficulties in diagnosis also emerge in distinguishing some exceptional sets, i.e. HL versus mediastinal primary B-cell lymphoma (MPBCL), or pleomorphic T-cell lymphomas versus T cell-rich large B-cell lymphoma or anaplastic large-cell lymphoma (ALCL), and also due to the fact that the lymphoma immunophenotipyc profile can occasionally be atypical, hampering recognition [14]. In some lymphomas, as in the case of HL, some DLBCL, and ALCL, FC has had a limited role in the diagnosis. Falsenegative results (reporting only to subsidiary reactive populations) have been assigned to the shortage of neoplastic cells present in these lymphomas, to cellular lysis during preparation, and to immunophenotypic background noise, conditioned by the subsidiary cell population (T-cell rosettes surrounding Reed-Sternberg cells), or due to the fact that neoplastic cells are too large to be detected by the flow cytometer $[13,15]$. The limitations of FC can be reduced in some situations by the complementary role of IHC as an alternative way to characterize cell populations. Some antigens, such as cyclin D1, are better evaluated by IHC. IHC also has the main advantage of providing simultaneous morphological control. In summary, FC and IHC are techniques that complement each other in the immunocharacterization of FNB lymphoid populations, reducing the risk of a misdiagnosis.
Histology and immunohistochemical stains are not devoid of interpretation problems and pitfalls. Evaluation of immunostains is a major challenge, with a moderate number of uninterpretable cases. Some antibodies, like CD103 and CD11c, useful in the diagnosis of hairy cell leukemia and nodal marginal zone lymphoma (MZL), cannot be used in paraffin sections.

Besides FC, other molecular techniques like FISH and PCR can also be performed with good results in FNB specimens as an alternative way to detect clonal populations by detecting IGH locus translocation, in the evaluation of $\mathrm{T}$-cell receptor rearrangements, or to detect specific translocations or deletions that help characterize a high proportion of lymphomas (table 1) [2]. Some of these molecular alterations also have important implications for prognostic evaluation and for the patient's selection of treatment, as in the case of $13 \mathrm{q} 14,11 \mathrm{q}$, and $17 \mathrm{q}$ deletion, associated with disease progression in CLL. The detection of specific cytogenetic aberrations is cardinal for the diagnosis of MCL, Burkitt lymphoma (BL), and FL [16-18].

As mentioned before, the ancillary techniques discussed in this review, which can contribute to the diagnosis and subclassification of lymphomas by FNB, are numerous and currently accessible to all of the main lymphoma diagnostic reference centers. However, they are costly and therefore should be used sparingly. In routine clinical practice, it is neither necessary nor cost effective to perform multiple tests in every specimen. Common sense and the cytopathologist's experience should determine how exhaustive the cytological diagnosis should be. It is also up to the cytopathologist to make a decision regarding the need to provide a comprehensive diagnosis or just an operative diagnosis, pushing a more accurate diagnosis for the histology. The effectiveness of FNB in the diagnosis of lymphomas depends on multidisciplinary team work to ensure an adequate sample and correlation between morphology and other ancillary techniques. The final report of an FNB lymphoid neoplasm should include the results of the several ancillary techniques that have been used to achieve the diagnosis, and a final interpretative conclusion should be provided [19].

\section{Indications for FNB of Lymph Nodes}

Although FNB may be used in a persistent reactive lymphadenopathy just to reassure the patient, this is not an optimal indication. FNB should preferably be confined to cases with a strong clinical suspicion of a specific infection such as tuberculosis or neoplasia. 
Table 1. Immunophenotype and genetic diagnostic/prognostic criteria for lymph node, current chronic B-cell lymphomas

\begin{tabular}{|c|c|c|c|}
\hline & Classic immunophenotype & Cytogenetic abnormalities & Clinical implications \\
\hline B-cell LL & $\begin{array}{l}\mathrm{CD} 45+, \mathrm{TDT}+, \mathrm{CD} 20+/-, \mathrm{CD} 79 b+, \mathrm{CD} 43+, \\
\mathrm{CD} 34+, \mathrm{CD} 10+/-\end{array}$ & $\begin{array}{l}\mathrm{t}(8 ; 13) ; \mathrm{t}(1 ; 14) \\
\mathrm{t}(10 ; 14) ; \mathrm{t}(5 ; 14)\end{array}$ & \\
\hline CLL & $\begin{array}{l}\text { Igsw }^{\mathrm{w}}, \mathrm{CD} 79 \mathrm{~b}+{ }^{\mathrm{w}}, \mathrm{CD} 45+, \mathrm{CD} 19+, \mathrm{CD} 20+^{\mathrm{w}}, \\
\mathrm{CD} 5+, \mathrm{CD} 23+, \mathrm{CD} 200+, \mathrm{CD} 43+, \mathrm{CD} 10-\end{array}$ & $\begin{array}{l}\mathrm{t}(14 ; 19) ; \text { del; } 11 \mathrm{q} 23^{10-20 \%} \\
\text { del } 13 \mathrm{q} 14.3^{30-50 \%} ; \text { del } 17 \mathrm{p}^{10 \%} ; \text { del } 6 \mathrm{q}\end{array}$ & Prognostic markers \\
\hline LPL & $\mathrm{CD} 45+, \mathrm{CD} 19+, \mathrm{CD} 20+, \mathrm{CD} 5-$ & $\mathrm{t}(9 ; 14)^{50 \%}$ & \\
\hline MCL & $\begin{array}{l}\mathrm{CD} 45+, \mathrm{CD} 79 b+, \mathrm{CD} 19+, \mathrm{CD} 20+, \mathrm{CD} 5+, \\
\mathrm{CD} 23-, \mathrm{CD} 43+, \mathrm{CD} 200-\end{array}$ & $\mathrm{t}(11 ; 14)^{90 \%}$ & Aggressive behavior \\
\hline $\begin{array}{l}\text { MZL } \\
\text { nodal }\end{array}$ & $\begin{array}{l}\mathrm{CD} 45+, \mathrm{CD} 19+, \mathrm{CD} 20+, \mathrm{CD} 5-, \mathrm{CD} 10-, \mathrm{CD} 23- \\
\mathrm{CD} 103-, \mathrm{CD} 11 \mathrm{c}+, \mathrm{CD} 43+{ }^{50 \%}\end{array}$ & $\begin{array}{l}\text { Trisomy } 18 ; 3 \\
1 \mathrm{q} 21 ; 1 \mathrm{q} 34\end{array}$ & \\
\hline $\mathrm{BL}$ & $\begin{array}{l}\mathrm{CD} 45+, \mathrm{CD} 19+, \mathrm{CD} 20+, \mathrm{CD} 10+, \mathrm{CD} 43+, \\
\mathrm{CD} 38++, \mathrm{Bcl} 2-\end{array}$ & $\mathrm{t}(8 ; 14) ; \mathrm{t}(2 ; 8) ; \mathrm{t}(8 ; 22)$ & \\
\hline DLBCL & $\begin{array}{l}\mathrm{CD} 45+, \mathrm{CD} 19+, \mathrm{CD} 20+, \mathrm{CD} 5+{ }^{10 \%} \\
\mathrm{CD} 10+{ }^{30-60 \%}\end{array}$ & $\begin{array}{l}\mathrm{t}(14 ; 18) \text {-myc rearrangement-30\% } 3 \mathrm{q} \text { and } 18 \\
\text { abnormalities, del } 6, \mathrm{t}(14 ; 18)^{4-5 \%} \\
\mathrm{t}(3 ; 14)^{30 \%}, \mathrm{t}(9 ; 14), \mathrm{t}(2 ; 17)^{<1 \%}, \mathrm{t}(2 ; 5) \text { - rare }\end{array}$ & Aggressive behavior \\
\hline $\mathrm{HCL}$ & $\begin{array}{l}\mathrm{CD} 45+, \mathrm{CD} 19+, \mathrm{CD} 20+^{\mathrm{B}}, \mathrm{CD} 103+, \\
\mathrm{CD} 22++, \mathrm{CD} 11 \mathrm{c}+, \mathrm{CD} 25+\end{array}$ & & \\
\hline
\end{tabular}

B-cell LL = B-cell lymphoblastic lymphoma; $\mathrm{W}=$ weak immunoexpression; $\mathrm{B}=$ bright expression.

Enlarged lymph nodes are more likely to be malignant in adults than in children. Furthermore, a solitary enlarged lymph node is more likely to be malignant. Enlarged lymph nodes in the posterior cervical triangle and in the supraclavicular area are more prone to being malignant than enlarged lymph nodes in other areas.

There are few, if any, true contraindications for the performance of FNB of lymph nodes if one excludes the uncooperative-patient situation. In patients with a bleeding diathesis, FNB is the safest modality to achieve a diagnosis. Pressure to the puncture site will reduce, if not prevent, hematoma formation.

\section{FNB: Technical Aspects}

\section{FNB and Sample Preparation}

FNB applies to palpable, superficial lesions as well as to deep lesions. Deep lesions can be dealt with the assistance of ultrasound and image-based guidance for placement of the needle. In most situations, FNB is performed by a radiologist or a pathologist. In our opinion, the best results are obtained when this technique is performed by a pathologist. FNB of lymph nodes requires more commitment than any other FNB done at any other location, and nothing is better than having the same expert responsible for the collection of the sample and for its assessment. FNB should be a bloodless technique. To perform FNB, any technique is suitable, provided that the operator obtains satisfactory results. In our experience, this task is facilitated through performance of a nonaspirative FNB technique, allowing, even for an unskilled operator, the achievement of good results and minimizing blood contamination. This nonaspirate technique, also called the Zajdela or fine-needle capillary method, relies on capillary action to draw the sheared cells into the small-caliber needle [20]. This technique gives the operator greater control over the target and reduces bleeding.

Adequate evaluation of the lymphoid cytomorphology relies on high cellularity samples and excellent technical preparation. Preparations can be air dried or sub- 
Fig. 1. FNB and sample management. PAS = Periodic acid-Schiff.

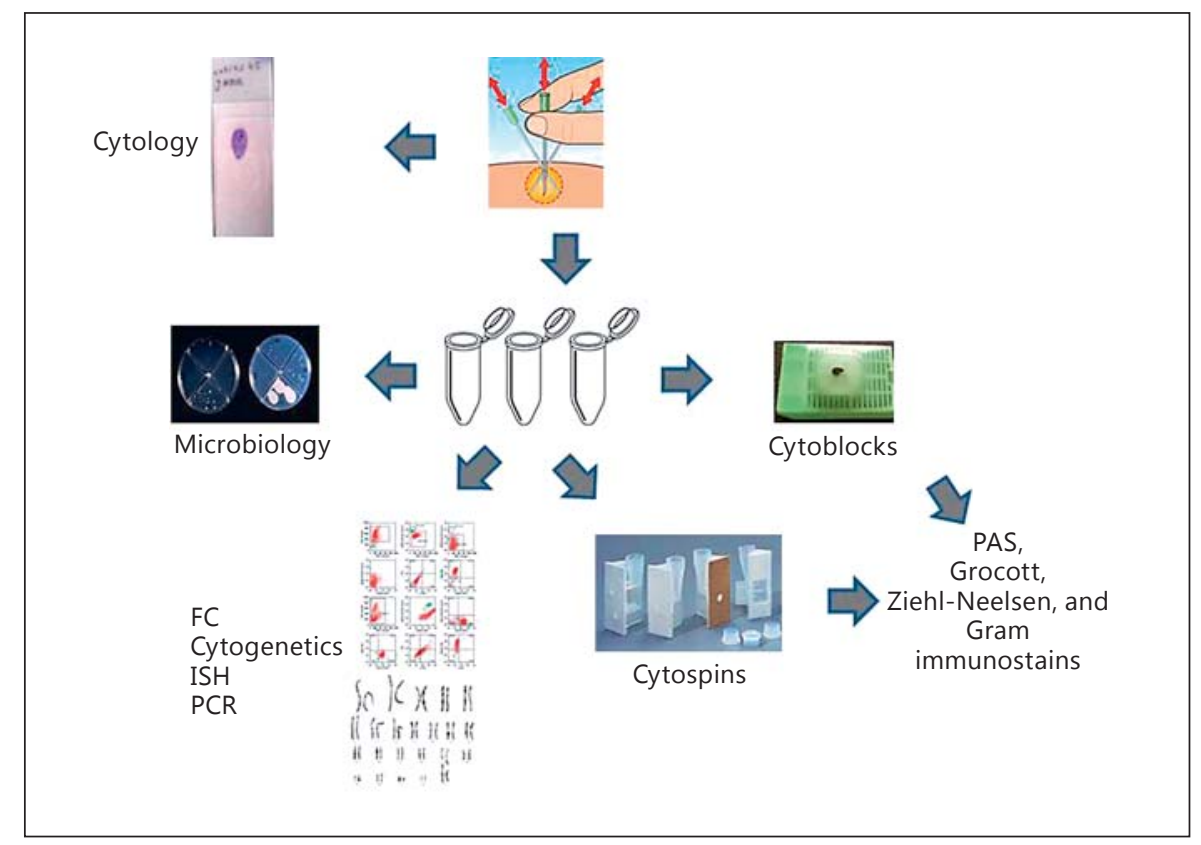

merged in alcohol at $95^{\circ} \mathrm{C}$ for subsequent staining with Giemsa or Papanicolaou and hematoxylin-eosin (H\&E), respectively. A wide cuvette with $95^{\circ} \mathrm{C}$ alcohol should be prepared in advance so that the smears can enter readily and without tilting into the alcohol to avoid cell drying. FNB should be performed using a 25 or higher gauge needle, with or without a mandrel. The choice of needle depends on the dimension of the lymph node and its depth. Shorter needles are easy to handle; however, they are devoid of a mandrel, hampering the delivery of the sample for other purposes. Longer needles, in general, have a mandrel, allowing a slow delivery and spread of the material, as the mandrel is pushed along the needle, for smearing and collection in Eppendorf tubes. The material collected in Eppendorf tubes can be further used in the preparation of cytospins and cell blocks or for ancillary techniques.

In palpable lesions, the lymph node should be blocked between 2 fingers (i.e. index and middle); in the case of axillary lymph nodes, the lymph node can be immobilized while pressing it against the thoracic wall with the fingers. The distance between the skin and the target should be shortened. The needle should slowly enter the lymph node, and small and slow movements (about 5-10) should be done back and forth, changing direction and avoiding bleeding. The needle direction can be changed by moving the nodule while pressing one or the other finger more intensely.
Material should not be allowed to flood into the needle cannon but only to occlude the hub of the needle. Whenever blood reaches the hub of the needle, the pass should be stopped immediately; blood damages the smear and compromises a second pass.

When dealing with a hard, sclerotic lymph node, the needle movements should be more vigorous. Small lymph nodes $(1 \mathrm{~cm}$ or less) may be easier to approach with a shorter needle.

In deep lymph nodes, FNB must be performed under ultrasound control. The shortest and most direct path for the needle should be chosen, obviating the risk of deviation. Attention should be paid regarding the excessive use of ultrasound gel. Gel should be applied to the ultrasound probe and this should be then covered with film to avoid contamination of the sample by the gel and to prevent observation in Giemsa-stained smears. Alcohol sprayed abundantly onto the skin can be used to permit the probe to slide.

ROSE for adequacy of the material, preliminary diagnosis, and triage for further ancillary techniques should be done (fig. 1). This observation can be accomplished using a rapid Wright-Giemsa type stain (e.g. Diff-Quik) in airdried smears. Additional material should always be collected for different purposes (cytospins/cell blocks, FC, and FISH/PCR) in case it is needed for a differential diagnosis. Material for further ancillary techniques, i.e. other than FC, should be collected in an Eppendorf tube (table 2). 
Table 2. Ancillary techniques that can be associated with FNB: aim, type of collection medium and preanalytical details

\begin{tabular}{|c|c|c|}
\hline Technique & Aim & Material collection \\
\hline FC & Immunophenotyping & $\begin{array}{l}\mathrm{PBS}^{1}, \text { TransFix }^{2}, \mathrm{RPMI}^{1} \\
\mathrm{EDTA}^{1}\end{array}$ \\
\hline Cytogenetics & Karyotyping & Saline solution, $\mathrm{RPMI}^{1,3}$ \\
\hline FISH & $\begin{array}{l}\text { Evaluation of molecular alterations, } \\
\text { translocation, deletions }\end{array}$ & $\begin{array}{l}\text { Cytospins, cytoblocks, } \\
\text { needle wash in saline } \\
\text { solution, RPMI, EDTA }\end{array}$ \\
\hline $\mathrm{CISH}$ & Evaluation of molecular alterations & Cytospins, cytoblocks \\
\hline
\end{tabular}

${ }^{1}$ The material must be processed during the first $6 \mathrm{~h} .{ }^{2}$ The material can be processed in 3 or 4 days. ${ }^{3}$ Collection in sterile conditions.
Cell blocks or cytospins should be always prepared for immunostains, useful in some differential diagnoses (e.g. cyclin D1, CD30, CD15, and PAX 5, among others) or in the evaluation of Ki 67. Material should be collected in PBS-buffered solution at $\mathrm{pH}$ 7.4. Both immunoalkaline phosphatase and immunoperoxidase immune techniques can be used on cytospins [21]. Material for cytogenetics or molecular analysis will also allow the search of specific translocations that characterize some lymphomas or evaluation of the molecular alterations that condition the selection of therapy for evaluation of the prognosis (table 2).

\section{Smear Staining and Evaluation}

Diff-Quik/Giemsa and H\&E/Papanicolaou are complementary stains that should be used whenever the amount of collected material allows. Prompt Diff-Quik/ Giemsa staining permits ROSE to be done in a shorter time. This stain highlights background details and emphasizes the heterogeneity and polymorphism of the cell population. It highlights the presence of fibrous connective tissue, cellular aggregates, eosinophilic cytoplasmic granulation, and other cytoplasm characteristics. H\&E/ Papanicolaou staining provides detailed information about the characteristics of the nucleus.

Most lymphadenopathies are mainly due to metastasis, inflammatory/infectious sets, or nonspecific hyperplasia. These clinicopathological sets are generally easily diagnosed with the joint work of FNB plus FC and immunostains. Zardawi et al. [22] reported a 99\% sensitivity in malignancy diagnosis, a $0 \%$ false negative

FC Fine-Needle Cytology in Lymph Nodes rate, and a $100 \%$ positive predictive value for malignancy diagnoses using the combination of FNB and FC $[22,23]$.

Two main sets should be considered in FNB diagnosis of a lymph node: nonneoplastic and neoplastic. The first set includes nonspecific reactive changes, inflammatory, specific infectious lesions, suppurative or granulomatous lymphadenitis, and, less frequently, lymphadenopathies of an unknown etiology like Kikuchi or Rosai-Dorfman disease. Histochemical stains like Gram, Grocott, and Ziehl-Neelsen can be performed to identify a putative infectious agent. Material can also be sent for microbiology tests or for PCR-based DNA methods to identify microorganisms.

In the neoplastic setting, the distinction between metastatic and malignant lymphoproliferative diseases should be made.

Metastatic tumors, mainly isolated cell carcinomas, small-cell tumors, small-cell carcinoma/neuroendocrine tumors in adults, and small-cell sarcomas in children, can pose difficult differential diagnostic problems which can be solved with the help of immunocytochemistry. In these contexts FC has little to add, and it is not useful for diagnosis. Nevertheless, some information can be retrieved if, while doing ROSE, misinterpretation of the smear determines that a sample has been collected for FC. Many of these small-cell tumors/carcinomas have neuroendocrine/neuroepithelial differentiation and are CD56 positive and CD45 negative and easily detected in FC.

The interpretation of FNB smears in lymph nodes suspicious for lymphoproliferative disorders will be discussed subsequently. 


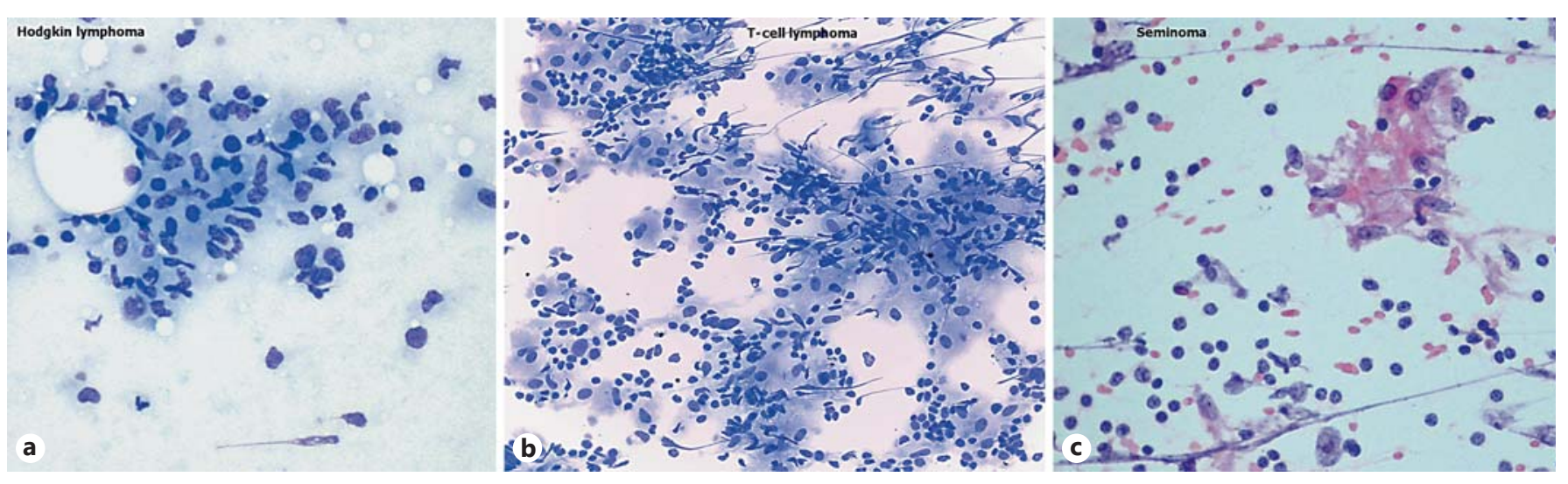

Fig. 2. Histiocytes with epithelioid features, isolated or in small granulomas/aggregates, can point to an HL (Giemsa, ×400; a), a T-cell lymphoma (Giemsa, $\times 200$; b), or even a seminoma (H\&E, $\times 400 ; \mathbf{c})$.

\section{Evaluation of a Smear Suspicious for Lymphoma}

Despite the impossibility of having a preserved architecture in a cytological smear, a good sample and a perfect smear will permit determination of whether lymphocytes lay in a diffuse towel or there are different morphological areas with cellular aggregates (representative of a germinal center), fibrotic fragments, or histiocytic aggregates (representative of a sinus histiocytosis). These details are, in some sets, a clue to a differential diagnosis; numerous histiocytes with epithelioid features, single or in small granulomas/aggregates, can point to an HL (fig. 2a), a Tcell lymphoma (fig. 2b), or even a seminoma (fig. 2c). A hard lymph node with fibrosis will provide a hypocellular smear which might indicate, in the proper clinical context, the possibility of HL (nodular sclerosis) or a primary mediastinal large B-cell lymphoma. Subsidiary cells dispersed in the background, like eosinophils or mast cells, can point to specific diagnoses such as HL, T-cell lymphoma, and lymphoplasmacytic lymphoma (LPL). Lymphohistiocytic aggregates with or without associated macrophages with tingible bodies are observed in follicular reactive hyperplasia, but they can also be present in some FL, in MCL, and in MZL. Otherwise, these aggregates of follicular dendritic cells should not be visible in CLL; instead, more clarified areas can be identified in the smear of a CLL, composed of prolymphocytes and paraimmunoblasts (fig. 3a).

Lymphoid lineage cell populations identifiable on an FNB smear of a lymph node are composed of small round lymphocytes (naive or memory cells), cleaved centrocytes, centroblasts, immunoblasts, prolymphocytes, paraimmunoblasts, plasmablasts, plasmacytoid lymphocytes, plasma cells, and monocytoid lymphocytes. When evaluating lymphocytic populations, two characteristics should be assessed: the homogeneity of the cell population and whether the lymphocytic population is monomorphous with a prevailing cellular type or there is a polymorphous population with a mixture of cells (small lymphocytes, centrocytes, centroblasts, immunoblasts, or plasma cells). A heterogeneous distribution and a polymorphic lymphocytic population, with cellular aggregates representative of germinal centers, usually point to nonspecific reactive follicular hyperplasia. Nevertheless, reactive hyperplasia may be quite varied, and it may be composed of monotonous smears with a predominance of small lymphocytes or else a predominance of large cells and immunoblasts, sometimes even with atypical forms (common in clinical conditions associated with viral infections, $\mathrm{HIV}$, or the Epstein-Barr virus) corresponding to paracortical hyperplasia (fig. 4). In this situation, the differential diagnosis of HL or T-cell lymphoma should be raised. Immunostains and FC may be employed in the characterization of these cases.

Some lymphomas, mainly FL and MZL, can also share a polymorphous and heterogeneous cytomorphology that simulates a reactive pattern (fig. 5a). In contrast, a monotonous and monomorphous lymphocytic population is highly suspicious for malignancy.

Another detail that should be evaluated in lymphoid populations is cell size. Lymphomas can be classified depending on whether they are composed of small (equal to or smaller than a resting lymphocyte or double the size of an erythrocyte - small naive lymphocytes, centrocytes, and prolymphocytes), medium-sized (centroblasts and paraimmunoblasts), or large cells ( 2 or 3 times the size 
Fig. 3. a CLL composed of small CLL typical lymphocytes with coarse chromatin, prolymphocytes, and paraimmunoblasts. H\&E. $\times 600$. b Immunophenotyping showing an abnormal B-cell (light blue) population expressing $\mathrm{CD} 20^{\mathrm{W}}, \mathrm{CD} 5+, \mathrm{CD} 23+, \mathrm{CD} 43+$, $\mathrm{CD}_{79} \mathrm{~b}^{\mathrm{W}}, \mathrm{CD} 200+$, with light chain $\lambda$ restriction. Color refers to the online version only.
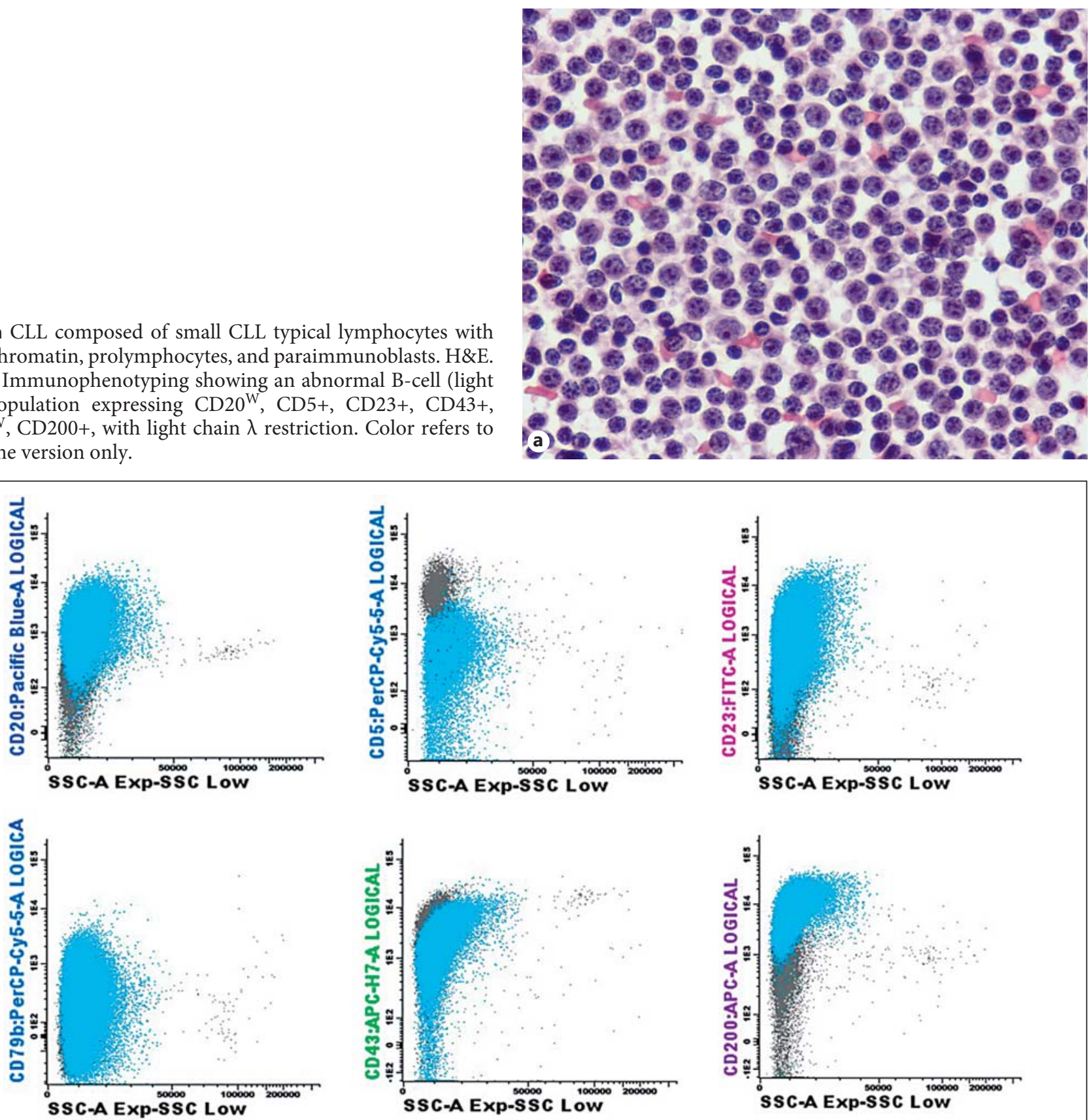

b

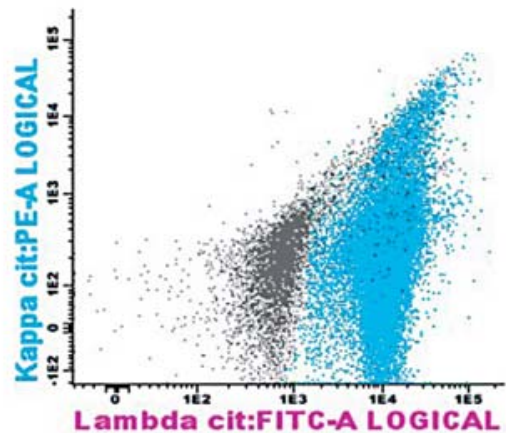

FC Fine-Needle Cytology in Lymph 
of a resting lymphocyte- immunoblast) (fig. 6). Nuclei should also be evaluated according to whether they are round, cleaved, or polilobulated and whether the chromatin is fine like in lymphoblasts or coarsely condensed as in CLL or BL. The nuclear membrane is also useful for characterization of lymphomas - MCL and FL are constituted by cleaved small centrocytes.

It is also essential to have knowledge of the lymphocytic evolution and transformation throughout their several sequential biological compartments. Each of these compartments is characterized by a specific morphology and immunophenotype and is the cell of origin of specific subtypes of lymphomas [24].

\section{Small/Intermediate-Sized Cell Lymphomas}

Small and intermediate-sized B-cell lymphomas encompass several differential diagnoses such as reactive lymphoid hyperplasia, as previously addressed, CLL, FL (grade 1-2), MCL, LPL, and MZL. All of these pathological entities share, at a low magnification, a similar morphological pattern which is characterized by small/intermediate lymphoid cells. However, at a high magnification, distinct morphological features can be perceived, providing helpful clues for determination of the proper diagnosis and guiding the selection of ancillary studies.

CLL is characterized by a monomorphic small/intermediate B-cell population composed of small lymphocytes with regular nuclei and coarse clumped chromatin. In some cases, and at a low amplification, clarified areas in the smear correspond to a variable percentage of prolymphocytes and paraimmunoblasts (fig. 3a). In general, patients with CLL present with a wide range of symptoms and multiple enlarged lymph nodes and the diagnosis is frequently made through peripheral blood analysis. Therefore, it is rather unusual that a first diagnosis of CLL be carried out in an FNB of an isolated lymph node. In most CLL patients, FNB is useful to exclude transformation in a high-grade lymphoma (Richter's transformation).

MCL (classic) is also characterized by a homogeneous monotonous small cell population of cleaved centrocytelike $B$ cells. The blastoid and pleomorphic variant will be addressed in the differential diagnosis of large-sized Bcell lymphomas. Although most cases have a characteristic immunophenotype (CD5+, CD200-, CD10-, CD23-), it is advisable to perform immunostaining with cyclin D1 or SOX11 in cytospins or cell blocks to confirm the diagnosis. FL, LPL, and MZL are composed of a more or less polymorphous lymphoid small/intermediate cell population. FL cytomorphology (grades 1-2) is in most situa-

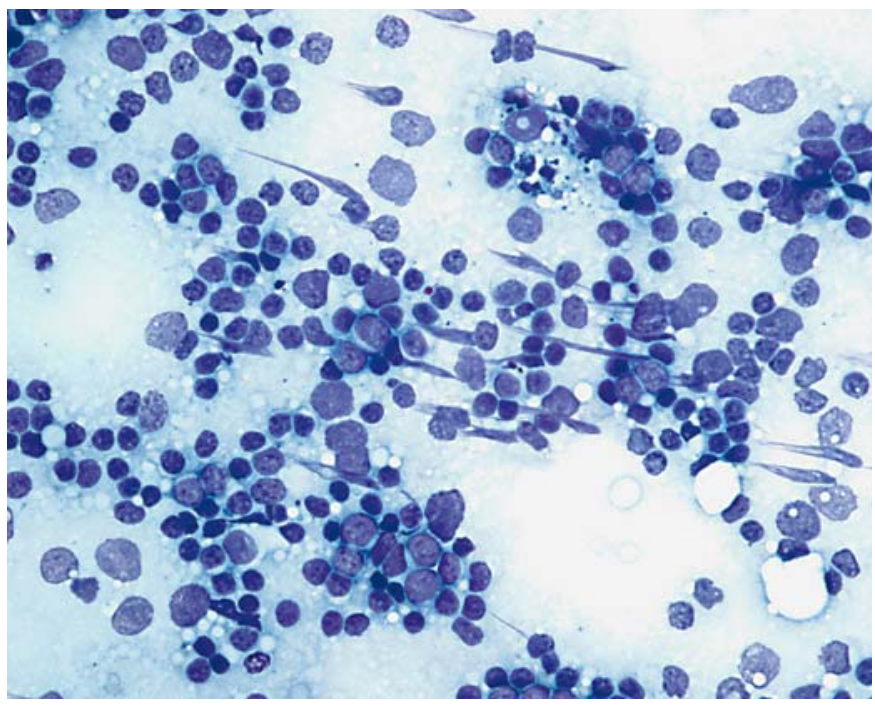

Fig. 4. Paracortical hyperplasia due to HIV infection. Numerous large atypical immunoblasts indicate a differential diagnosis of lymphoma. Immunostains and FC may be employed for characterization of these cases. H\&E. $\times 400$.

tions indistinguishable from a reactive follicular hyperplasia. At a high magnification, attention should be paid to the scarceness of small naive lymphocytes and to the high percentage of centrocytes and centroblasts. FL also frequently displays lymphohistiocytic aggregates and macrophages with tingible bodies as seen in reactive lymphoid hyperplasia. Grading of FL can be performed in cytology, but this is not universally accepted $[25,26]$. The distinction between grades 1 and 2 is poorly reproducible and has no clinical/therapeutic implications. Grade $3 \mathrm{FL}$ are considered in the differential diagnosis with largesized B-cell lymphomas.

LPL is characterized by a homogeneous polymorphic population with a mixture of small lymphocytes and a variable number of plasmacytoid lymphocytes and mature plasma cells. Mast cells are commonly identified in the subsidiary population. Differential diagnosis with MZL can be morphologically difficult, and ancillary testing as well as correlation with the clinical presentation are necessary. LPL patients have, in most cases, monoclonal IgM in the serum (Waldenström macroglobulinemia). MZL can present as a monotonous intermediate-sized cell smear, but more frequently it consists of a polymorphic cell population with small lymphocytes, centrocytelike cells, centroblasts, plasmacytoid lymphocytes, plasma cells, and monocytoid cells. This type of lymphoma is rare and represents a challenge for cytological diagnosis; it has no characteristic immunophenotype and its cyto- 


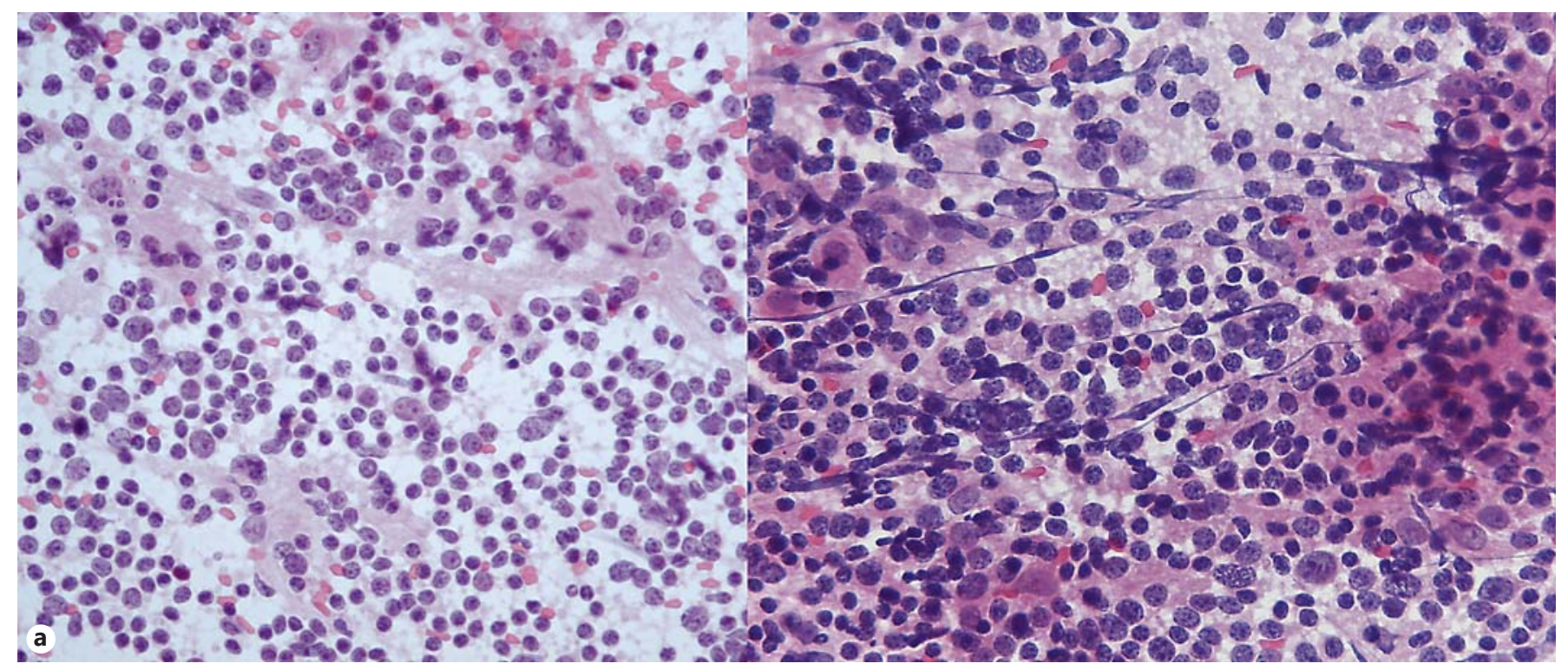

Fig. 5. a FL (left) can display a polymorphous and heterogeneous morphology simulating a reactive pattern (right). $\mathrm{H} \& \mathrm{E}$. $\times 400$. b Immunophenotyping. FL abnormal B-cell population (light blue): $\mathrm{CD} 10+{ }^{\mathrm{B}}$, $\mathrm{CD} 38+$ heterogeneous, with light chain $\kappa$ restriction. Color refers to the online version only.
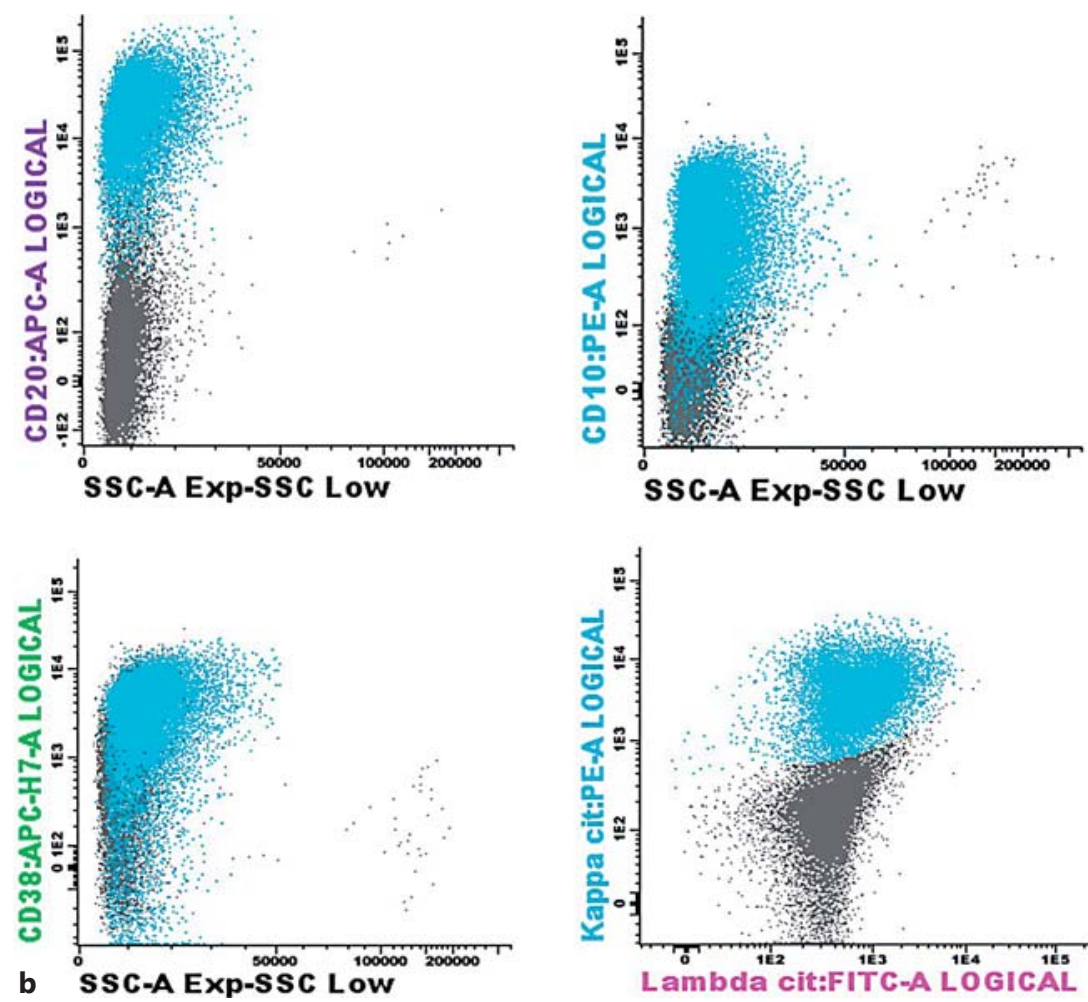

morphological characteristics overlap with those of other small-cell lymphomas and even reactive processes. Unlike extranodal MZL, nodal MZL lacks specific molecular markers like MALT1 and it is frequently a diagnosis of exclusion [27].

FC Fine-Needle Cytology in Lymph Nodes
Lymphoblastic lymphomas and BL are sometimes considered medium-sized lymphomas, but in general they pose differential diagnostic problems mainly with large-sized lymphomas and will be addressed later [28]. 

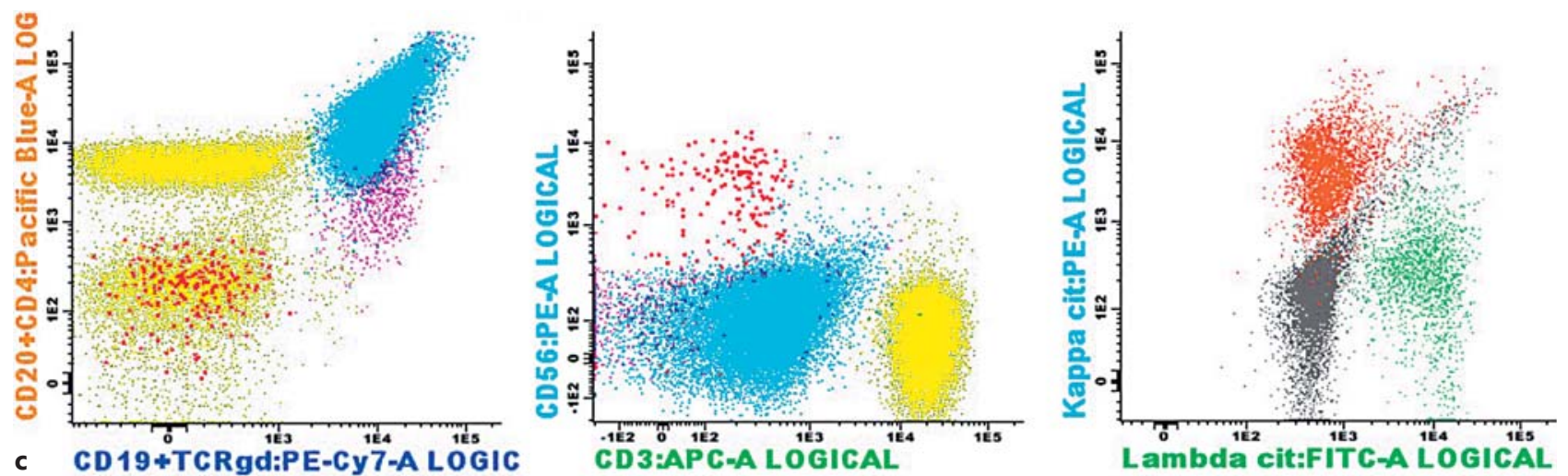

Fig. 5. c Reactive B-cell polyclonal population (light blue) expressing light chain $\kappa$ (orange) and light chain $\lambda$ (green) restriction, T cells (yellow), NK cells (red), and plasma cells (pink). Colors refer to the online version only.

Fig. 6. Evaluation of non-Hodgkin lymphoma based on cell size and cytomorphology.

\begin{tabular}{|c|c|c|c|}
\hline Cytomorphology & Monomorphic & $\begin{array}{l}\text { Small cells } \\
\text { Medium cells } \\
\text { Large cells }\end{array}$ & $\begin{array}{l}\text { Small lymphocytic lymphoma } \\
\text { LPL } \\
\text { MZL } \\
\text { MCL } \\
\text { FL (grade 1) } \\
\text { Reactive lymph node } \\
\text { Lymphoblastic lymphoma } \\
\text { BL } \\
\text { MCL (blastoid) } \\
\\
\text { FL (grade 3) } \\
\text { Large-cell lymphoma } \\
\text { Anaplastic T-cell lymphoma } \\
\text { MZL } \\
\text { FL } \\
\text { T-cell lymphoma } \\
\text { T-cell-rich B-cell lymphoma } \\
\text { Reactive lymph node }\end{array}$ \\
\hline
\end{tabular}

\section{Large-Sized Lymphomas}

Large-sized B-cell lymphomas, whose paradigm is DLBCL, include other differential diagnoses such as reactive lymphoid hyperplasia, FL (grade 3), BL, blastoid MCL, HL, lymphoblastic lymphoma, anaplastic T-cell lympho$\mathrm{ma}$, and grey-zone lymphomas. DLBCL account for the great majority of non-Hodgkin lymphomas and they encompass different variants, some of which should be highlighted. Although it is not crucial to individualize subtypes like centroblastic versus immunoblastic DLBCL, other subtypes like primary mediastinal B-cell lymphoma and T- cell/histiocyte-rich large B-cell lymphoma should be identified and represent a major challenge for FNB diagnosis.

Morphologically, DLBCL displays variable cytomorphological characteristics, reflecting the variability of its biology and pathogenicity. Smears are in general highly cellular and they display a more or less heterogeneous and polymorphic large cell population on a necrotic background with apoptotic bodies and macrophages with tingible bodies (fig. 7a). Nuclear features are variable, including round or irregular nuclei and a variable number of nucleoli. 
Fig. 7. a DLBCL display variable cytomorphological characteristics, reflecting the variability in their biology and pathogenicity. Smears are in general highly cellular and display a more or less heterogeneous and polymorphic large cell population on a necrotic background with apoptotic bodies and macrophages with tingible bodies. Nuclear features are variable, including round or irregular nuclei and a variable number of nucleoli. H\&E. $\times 600$. b Immunophenotyping of DLBCL: T cells (yellow); large and abnormal B-cell population (red): CD20+, CD5-, CD10-, with light chain $\kappa$ restriction. Colors refer to the online version only.
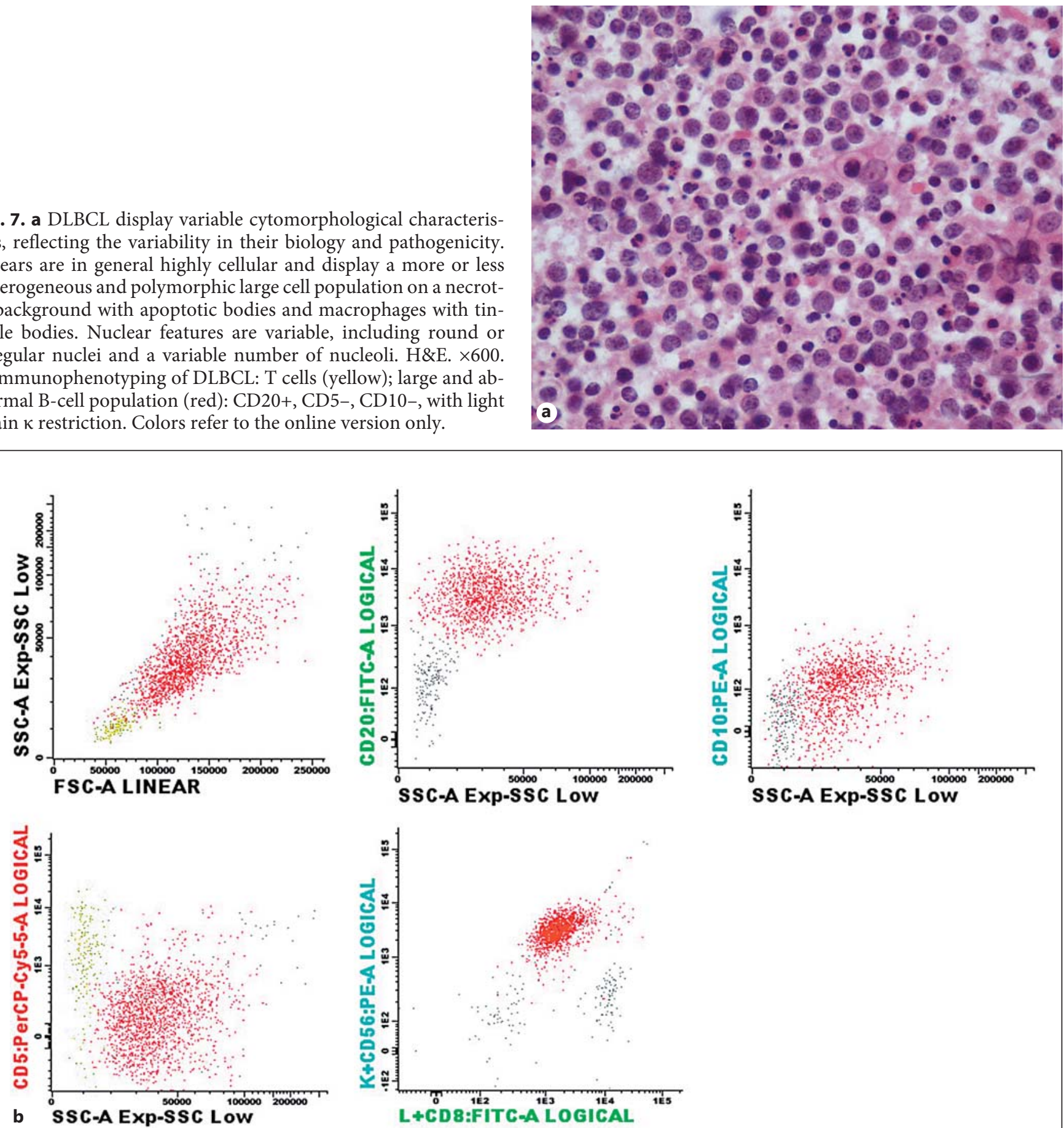

To better understand this group of lymphomas, a huge effort has been made to correlate the cell of origin to distinct molecular subgroups with different immunocytochemical features, outcomes, and responses to target therapy. Based on the cell of origin, at least 3 subgroups of
DLBCL were identified, i.e. germinal center B-cell-like (GCB), activated B-cell-like (ABC), and unclassifiable DLBCL [29]. Patients with $A B C$ and unclassifiable DLBCL seem to respond less effectively to therapeutic regimens and have worse survival [30]. Immunohistochemi- 


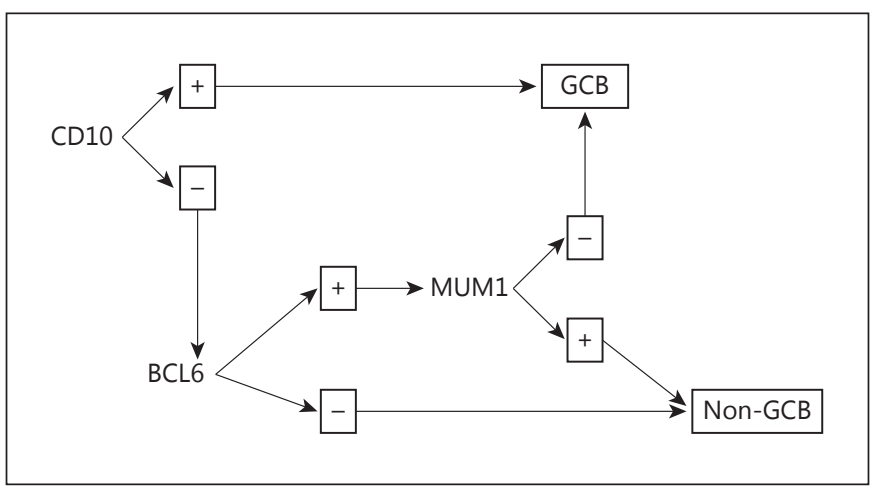

Fig. 8. Immunohistochemical algorithm for the classification of DLBC. Hans algorithm.

cal algorithms, which can be performed in surgically resected specimens, FNB cell blocks, or cytospins, have been developed to identify these subgroups $[31,32]$. The most frequent algorithm for subtyping of the cell of origin subgroups includes antibodies like CD10, BCL6, and MUM1 and it shows about $80 \%$ concordance with the gene expression profile molecular subgroups (fig. 8) [32, 33]. More recently other algorithms were proposed with CD10, FOXP1, GCET-1, MUM1, and BCL6, gaining 92.6\% concordance with the gene expression profile molecular subgroups [34], yet their use has not become widespread since they involve antibodies not used routinely in most laboratories. However, with restricted use FC can, through CD10 expression, guide in GCB or ABC DLBCL subtyping.

Most DLBCL NOS lymphomas are easily diagnosed in cytological preparations, but in some cases differential diagnostic problems arise with carcinomas, melanomas, and even seminomas. This is easily solved by using FC or immunostains in cytospins or cell blocks.

BL (fig. 9a) is characterized by a monotonous monomorphic large cell population. Characteristically, BL cells display typically coarse chromatin and cytoplasm featuring small lipidic vacuoles (fig. 9a; Giemsa).

The blastoid variant of MCL should also be included in the differential diagnosis of monotonous large B-cell lymphomas. FC and immunostaining with SOX11 and cyclin D1 can be helpful in the diagnosis.

Polymorphic large-cell lymphomas include anaplastic T-cell lymphomas, composed of large pleomorphic cells with strange shapes (horseshoe) and great variability. These tumors overlap with, and are difficult to distinguish from, cHL [35, 36]. Both have CD30-positive pleomorphic neoplastic cells; both display an inflammatory background that can be rich in epithelioid histiocytic cells and eosinophils. Neoplastic cells in anaplastic T-cell lymphomas express T-cell markers, CD30, and EMA, and $60-80 \%$ of the cases express ALK-1. On the other hand, Reed-Sternberg cells express PAX 5, CD30, and EMA and do not express T-cell markers.

Another polymorphic large-cell lymphoma that can be confused with HL is mediastinal large B-cell lymphoma. The smears display a polymorphous cell population with large atypical cells and small lymphocytes. Histiocytes, as well as an inflammatory background, can be present. Like the mediastinal nodular sclerosis variant of HL, this lymphoma presents sclerotic areas, poorly conditioning cellular smears that are difficult to assess. Smears can bare large pleomorphic Reed-Sternberg-like cells that can be CD30 positive. Although most authors do not recommend sending a cHL-suspicious sample for immunophenotyping, in these situations characterization of the background cell population will add helpful information. Entities like $\mathrm{cHL}$ and mediastinal large B-cell lymphoma are somehow related, showing biological similarities, and recently in the 2008 WHO classification of lymphomas a provisional entity designated as B-cell lymphoma, unclassifiable, with features intermediate between DLBCL and $\mathrm{CHL}$, was recognized [1].

\section{Flow Cytometry}

FC is a technology composed of a refined array of lasers, optics, fluidics, and electronic detectors capable of measuring light scatter and/or fluorescence emission from cells. This technique enables therefore the analysis and quantification of multiple cellular characteristics from a purified cellular suspension that is hydrodynamically focused on a single cell-wide laminar flow column.

Immunophenotyping by $\mathrm{FC}$ has become a standard routine in the diagnosis and monitoring of hematological malignancies. The principle of this technique is based on the conjugation of fluorochrome-labeled antibodies that bind to specific antigens.

Flow cytometers involve 3 major components: a fluidic, an optical, and an electronical system. The fluidic system carries particles (one by one) in a fluid stream across a laser beam for interception; the optical system includes lasers that provide a light source and optical filters to direct the light signals to each detector, and the electronics system converts light signals into electronic signals which in turn are converted to channel numbers by the analogto-digital converter for further computer processing. This technique can provide information based on the physical properties of each individual cell, including relative size (based on forward-scattered light), relative granularity or 


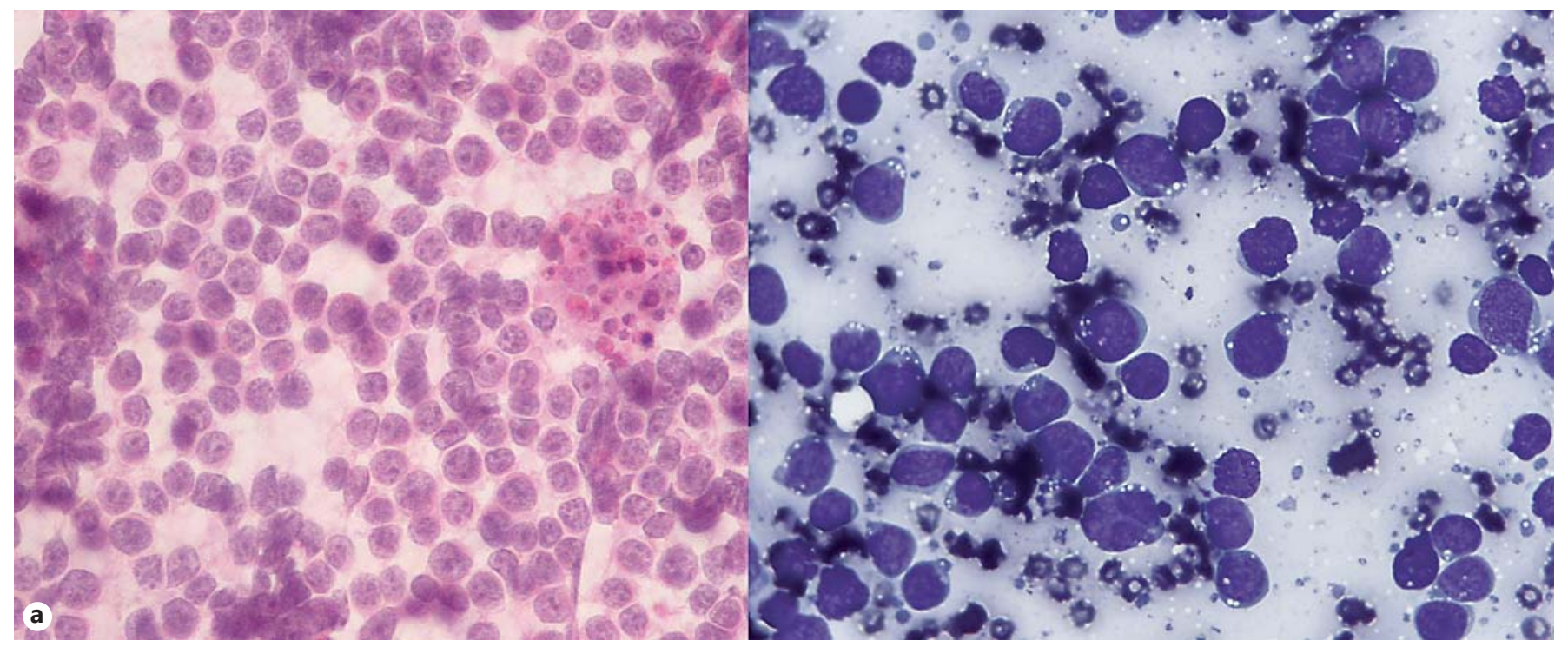

Fig. 9. a BL is characterized by a monotonous monomorphic large cell population. Characteristically, BL cells display a typical coarse chromatin (right; H\&E, $\times 400$ ), and cytoplasm featuring small lipidic vacuoles (left; Giemsa, ×600). b Immunophenotyping of BL. Abnormal B-cell population (red): CD10+, CD38+ ${ }^{\mathrm{B}}$, LAIR1-, with light chain $\kappa$ restriction. Color refers to the online version only.
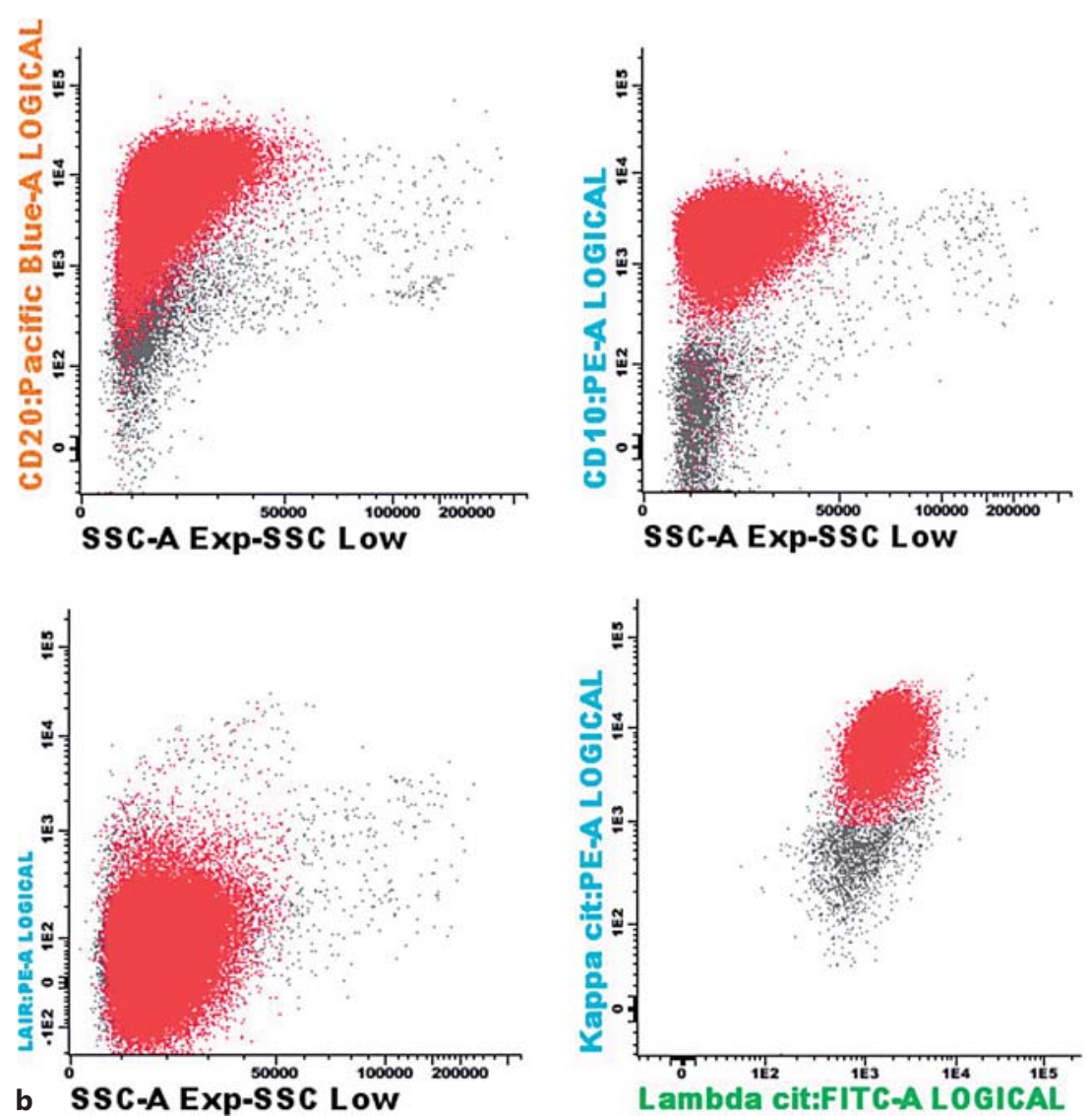

FC Fine-Needle Cytology in Lymph Nodes 
internal complexity (based on side-scattered light - the higher the complexity the greater the amount of side-scattered light), and the expression of surface and cytoplasmic antigens. For the evaluation of intracellular markers, the cells must be fixed to ensure the stability of soluble antigens, and a cell permeabilization step prior to staining is required. The analyzed parameters are displayed in several graphic representations like histograms and dot plots. The term 'gating strategy' is used to define a restricted population that we want to study or characterize.

Immunophenotyping by FC applied to the study of lymphadenopathies and to the diagnosis of lymphoma has become routine practice, and it is nowadays recognized for its effectiveness. This technique allows objective observation of lymphocytes, with quantification and characterization, to distinguish abnormal from reactive populations.

The recent development of a great number of flow cytometers, software acquisition/analysis programs, different combinations of monoclonal antibodies, the use of a growing number of fluorochromes, the complexity of instrument settings, calibration, and novel protocols adapted to each work group have led to a complex process which is highly dependent on the expertise of the operator and needs to be accurate. It is essential to implement standardization in all steps of the pre- and postanalytic phases. Standardization involves numerous steps that include the use of monoclonal antibodies versus fluorochrome panels, the implementation of protocols for laboratory procedures, and definition of the appropriate software tools to recognize immunophenotipyc patterns for multivariate analysis of the data.

Therefore, prompted by the need to optimize and standardize flow cytometric tests for diagnosis, prognosis, and evaluation of the treatment effectiveness of hematological malignancies, an important group, i.e the European Union EuroFlow Consortium, emerged in 2005. At the time of reporting, EuroFlow was an independent Scientific Working Group of the European Hematology Association, and it encompassed a total of 20 diagnostic research groups and 11 countries in Europe and America [37]. With the creation of the EuroFlow Group, numerous protocols have been developed with the aim of standardizing the several proceedings involved in the entire pre- and postanalytical processes. The use of these protocols in laboratories has brought about a great evolution in the establishment of accurate diagnoses.

Protocols for the diagnosis and classification of hematological malignancies consist of a sequential combination of screening tubes that address a succession of specific questions.
Included in this analytic protocol are at least 2 types of cellular markers which were carefully chosen, i.e. backbone markers, which are used to identify distinct cell populations, and characterization markers, which are used to characterize target populations. Backbone markers expectedly identify both normal and malignant cells, and they are usually placed in all of the analytic panels in the same fluorocrome position, conditioning a constant and identical location of the target population and allowing automated gate setting of the target population. In contrast to backbone markers, which are present in the first screening tube as well as in the multitube panel, characterization markers are present only once in one tube of the panel, and they are chosen in accordance with the target population previously identified. In the EuroFlowchosen protocols, the best possible combinations of backbone markers and characterization markers were designed. Each marker is selected based on its contributing information combined with all of the other markers of the panel.

In a first approach and as a critical prerequisite, an appropriate algorithm should be designed for sequential use of the different markers. For most lymphoma diagnoses, a rapid screening tube (lymphoid screening tube - backbone markers) is used to identify all relevant cell subcategories present in the sample (B, T, and NK cells) and to detect the presence of abnormal light chain-restricted populations (table 3 ). In a second step, several appropriate characterizing markers are selected to classify $\mathrm{B}, \mathrm{T}$, or NK cell chronic lymphoprolipherative disorders according to WHO-defined disease categories (table 4). Labelling for the different antibodies is assessed using positivity and negativity but also MFI. CD45 is an important marker to discriminate, based on its MFI, mature from immature lymphocytes. CD19 and CD20, together with CD45, allow subtyping into mature $\mathrm{B}$ lymphocytes (CD19+, CD20+ bright, and CD45+ bright) and B-cell precursors (CD19+, CD20-/low intensity, and CD45+ low intensity). Pan B-cell markers like CD19, CD20, and CD22, as well as surface membrane and cytoplasmic immunoglobulins, are used to demonstrate B-cell nature and light chain restriction. CD2, CD3, CD4, CD5, and CD7 are used to characterize T cells. NK cells should express antibodies of mature lymphocytes (CD45+ bright) and CD56 in the absence of CD19; plasma cell backbone markers are CD45, CD19, and CD38. Additional markers are included to complement the subsets of B cells, T cells, and plasma cells (table 4).

MFI expression of some antibodies, is also used to characterize some specific subtypes of lymphomas. Un- 
derexpression of CD20 is expected in CLL (fig. 3b), and underexpression of CD19 occurs in FL and DLBCL. Bright expression of CD20 is expected in FL (fig. 5b) and hairy cell lymphoma (HCL). CD10 is expressed in cells from the follicular germinal center, but it is also characteristic of immature B or T cells. The CD10 expression in FL is generally brighter than that in normal lymphocytes from the germinal center. High levels of CD200 are present in HCL and CLL (fig. 3b), whereas low levels of this antigen could be found in MCL and BL. Leukocyte-associated immunoglobulin-like receptor 1 (LAIR1) is overexpressed in HCL. LAIR1 is also an important marker for differential diagnosis between MCL and FL. The existence of different MFI justifies the use of a set of markers that at first glance might appear to have a tag overlay.

Other markers like CD38 are important backbone markers in plasma cell disorders, but they can also have a role as characterizing markers, such as in FL (fig. 5b), BL (fig. 9b), DLBCL (fig. 7b), FL, plasmablastic lymphoma, and other malignancies with plasmacytoid differentiation, or even in providing information on the prognosis of some lymphomas, such as in CLL.

\section{Conclusions}

There is a consensus that the current diagnosis of lymphoma by FNB is usually based on the combined work of clinics, morphology, immunophenotyping, and cytogenetics. In the majority of cases, this joint work allows achievement of an accurate diagnosis of malignancy and even correct subcharacterization in routine lymphomas.

Constant updating and the recent development of a great number of flow cytometers, software acquisition/ analysis programs, different combinations of monoclonal antibodies, instrument settings, calibration, and novel protocols adapted to each work group have led to a complex process that needs to be accurate. It is important to implement standardization in the common use of monoclonal antibodies versus fluorochrome panels, as well as in laboratory procedures and instrument settings, to improve the diagnosis of hematological diseases. EuroFlow protocols are continuously evolving and being refined by experts (EuroFlow Group). With the evolution of science and in particular of molecular biology, new entities are being diagnosed and new markers will be added to the previously existing panels.

Several constraints can pose difficulties in differential diagnosis. Cytomorphology can be atypical in some cases, and the immunophenotipyc profile can be aberrant, over-

FC Fine-Needle Cytology in Lymph Nodes
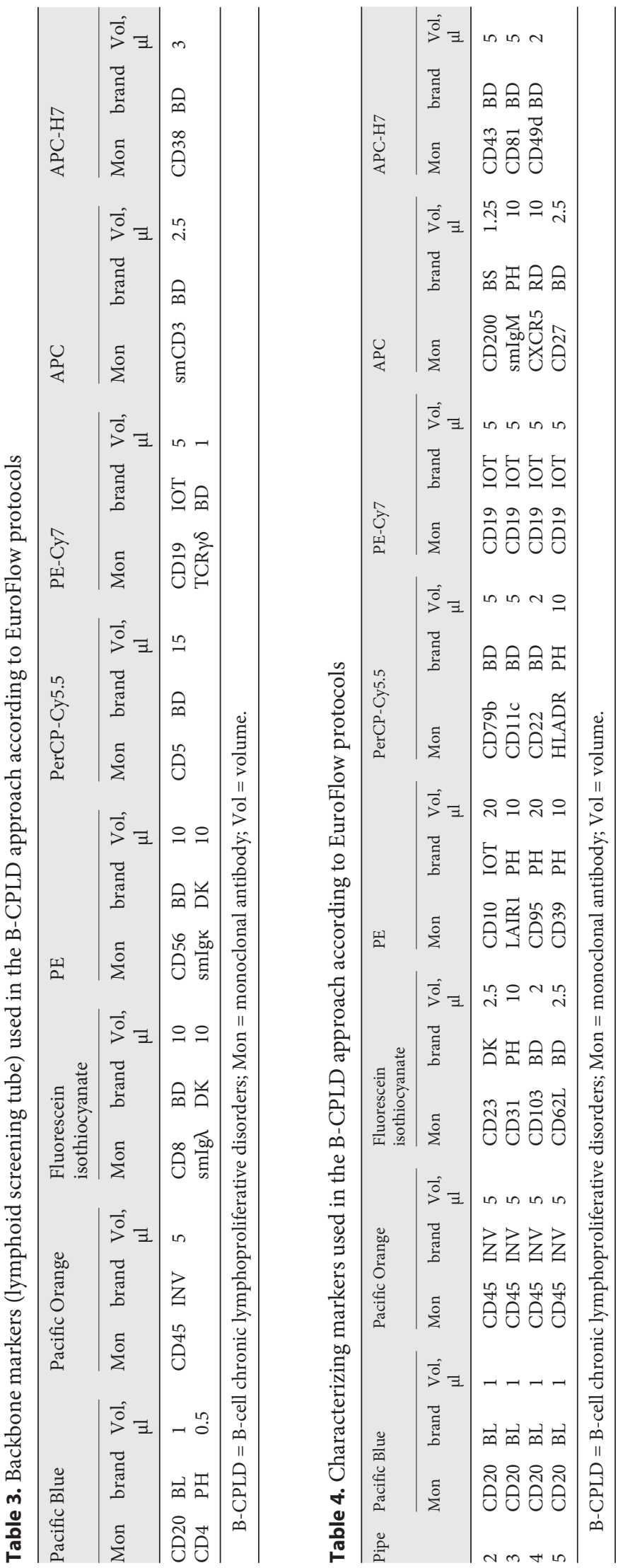

Acta Cytologica 2016;60:284-301 DOI: $10.1159 / 000448679$ 
lapping with other entities. New immunocytochemical markers, such as SOX11, HGAL, LMO2, and LEF1, among others, have emerged and are contributing to a more accurate diagnosis [29]. Additionally, in selected cases, the use of molecular techniques may be helpful, since many lymphomas have genetic features that, in the appropriate clinical, morphological, and immunophenotypical context, can help in the diagnosis.

\section{Acknowledgments}

The authors thank Prof. Manuel Sobrinho Simões (MD, PhD) for his support and review of this work. The authors also thank Dr. Evelina Mendonça (MD), Dr. Conceicao Saldanha (MD), and Dr.
Jorge Candeias (MD) for their encouragement towards the development of this scientific area and diagnostic technique.

We did not receive a grant for the conduction of this study; all the costs were covered by the Centro Hospitalar de S. João (Porto, Portugal) as routine work.

\section{Disclosure Statement}

The authors have no affiliation with or involvement in any organization or entity with any financial interest (such as: honoraria; educational grants; participation in speakers' bureaus; membership, employment, consultancy, stock ownership, or other equity interest, and expert testimony or patent-licensing arrangements) or nonfinancial interest (such as personal or professional relationships, affiliations, knowledge, or beliefs) in the subject matter or materials discussed in this paper.

\section{References}

1 Swerdlow SH, Campo E, Harris NL, et al: WHO classification of haematopoietic and lymphoid tissues. Lyon, IARC Press, 2008.

-2 Zeppa P, Sosa Fernandez LV, Cozzolino I, Ronga V, Genesio R, Salatiello M, Picardi M, Malapelle U, Troncone G, Vigliar E: Immunoglobulin heavy-chain fluorescence in situ hybridization-chromogenic in situ hybridization DNA probe split signal in the clonality assessment of lymphoproliferative processes on cytological samples. Cancer Cytopathol 2012;120:390-400.

3 Kocjam G: Cytological and molecular diagnosis of lymphoma. J Clin Pathol 2005;58:561567.

4 Cancer: New Registrations and Deaths. Wellington, Ministry of Health, 2010.

5 Zeppa P, Marino G, Troncone G, Fulciniti F, De Renzo A, Picardi M, Benicasa G, Rotoli B, Vetrani A, Palombini L: Fine-needle cytology and flow cytometry immunophenotyping and subclassification of non-Hodgkin lymphoma. Cancer Cytopathol 2003;102:55-65.

6 Dong HY, Harris NL, Preffer FI, Pitman MB Fine-needle aspiration biopsy in the diagnosis and classification of primary and recurrent lymphoma: a retrospective analysis of the utility of cytomorphology and flow cytometry. Mod Pathol 2001;14:472-481.

7 Meda BA, Buss DH, Woodruff RD, et al: Diagnosis and subclassification of primary recurrent lymphoma: the usefulness and limitations of combined fine-needle aspiration cytomorphology and flow cytometry. Am J Clin Pathol 2000;113:688-699.

8 Cheson BD, Fisher RI, Barrington SF, Cavalli F, Schwartz LH, Zucca E, Lister TA, et al: Recommendations for initial evaluation, staging, and response assessment of Hodgkin and non-Hodgkin lymphoma: the Lugano classification. J Clin Oncol 2014;32:3059-3068.
-9 Tilly H, Gomes da Silva M, Vitolo U, Jack A, Meignan M, Lopez-Guillermo A, Walewski J, André $\mathrm{M}$, Johnson PW, Pfreundschuh $\mathrm{M}$, Ladetto M; ESMO Guidelines Committee: Diffuse large B-cell lymphoma (DLBCL): ESMO Clinical Practice Guidelines for diagnosis, treatment and follow-up. Ann Oncol 2015;26(suppl 5):v116-v125.

10 Langerak AW, van Den Beemd R, WolversTettero IL, et al: Molecular and flow cytometry analysis of the $\mathrm{V} \beta$ repertoire for clonality assessment in mature TCR $\alpha \beta$ T-cell proliferations. Blood 2001;98:165-173.

11 Beck RC, Stahl S, O’Keefe CL, Maciejewski JP, Theil KS, Hsi ED: Detection of mature T-cell leukemias by flow cytometry using anti-T-cell receptor V $\beta$ antibodies. Am J Clin Pathol 2003;120:785-794.

12 Fromm JR, Thomas A, Wood BL: Flow cytometry can diagnose classical Hodgkin lymphoma in lymph nodes with high sensitivity and specificity. Am J Clin Pathol 2009;131: 322-332.

13 Roshal M, Wood BL, Fromm JR: Flow cytometric detection of the classical Hodgkin lymphoma: clinical and research applications. Adv Hemathol 2011;2011:9.

14 Das DK, Francis IM, Sharma PN, Sathar SA, John B, George SS, Mallik MK, Sheikh ZA, Haji BE, Pathan SK, Madda JP, Mirza K, Ahmed MS, Junaid TA: Hodgkin's lymphoma: diagnostic difficulties in fine-needle aspiration cytology. Diagn Cytopathol 2009;37: 564-573.

15 Irsch J, Nitsch S, Hansmann M-L, Rajewsky K, Tesch H, Dieh V, Jox A, Küppers R, Radbruch A: Isolation of viable Hodgkin and Reed-Sternberg cells from Hodgkin disease tissues. Proc Natl Acad Sci USA 1998;95: 10117-10122.
Caraway NP: Evolving role of FNA biopsy in diagnosing lymphoma: past, present, and future. Cancer Cytopathol 2015;123:389393.

-17 da Cunha Santos G, Ko HM, Geddie WR, Boerner SL, Lai SW, Have C, Kamel-Reid S, Bailey D: Targeted use of fluorescence in situ hybridization (FISH) in cytospin preparations: results of 298 fine needle aspirates of B-cell non-Hodgkin lymphoma. Cancer Cytopathol 2010;118:250-258.

18 Monaco SE, Teot LA, Felgar RE, Surti U, Cai G: Fluorescence in situ hybridization studies on direct smears: an approach to enhance the fine-needle aspiration biopsy diagnosis of Bcell non-Hodgkin lymphomas. Cancer 2009; 117:338-348.

19 Jaffe ES, Banks PM, Nathwani B, et al: Recommendations for the reporting of lymphoid neoplasms: a report from the association of directors of anatomic and surgical pathology. Mod Pathol 2004;17:131-135.

20 Zajdela A, Zillhardt P, Voillemot N: Cytological diagnosis by fine needle sampling without aspiration. Cancer 1987;59:1201-1205.

21 Skoog L, Tani E: FNA Cytology in the Diagnosis of Lymphoma. Monogr Clin Cytol. Basel, Karger, 2009, vol 18, pp 5-10.

22 Zardawi IM, Jain S, Bennett G: Flow cytometry algorithm on fine needle aspirates for clinical workup of patients with lymphadenopathy. Diagn Cytopathol 1998;19:274-278.

23 Hirachand S, Lakhey M, Akhter J, Thapa B: Evaluation of fine needle aspiration cytology of lymph nodes in Kathmandu Medical College, Teaching Hospital. Kathmandu Univ Med J 2009;26:139-142.

24 LeBien TW, Tedder TF: B lymphocytes: how they develop and function. Blood 2008;112: 1570-1580. 
25 Brandao GD, Rose R, McKenzie S, Maslak P, Lin O: Grading follicular lymphomas in fineneedle aspiration biopsies: the role of ThinPrep slides and flow cytometry. Cancer 2006; 108:319-323.

26 Young NA, Al-Saleem TI, Al-Saleem Z, Ehya $\mathrm{H}$, Smith MR: The value of transformed lymphocyte count in subclassification of nonHodgkin's lymphoma by fine-needle aspiration. Am J Clin Pathol 1997;108:143-151.

27 van den Brand M, van Krieken JH: Recognizing nodal marginal zone lymphoma: recent advances and pitfalls - a systematic review. Haematologica 2013;98:1003-1013.

28 Caraway NP: Strategies to diagnose lymphoprolioherative disorders by fine-needle aspiration by using ancillary studies. Cancer $\mathrm{Cy}$ topathol 2005; 105:432-442.

29 Ondrejka SL, Hsi ED: Pathology of B-cell lymphomas: diagnosis and biomarker discovery. Cancer Treat Res 2015;165:27-50.

-30 Alizadeh AA, Eisen MB, Davis RE, et al: Distinct types of diffuse large B-cell lymphoma identified by gene expression profiling. $\mathrm{Na}$ ture 2000;403:503-511.
Cozzolino I, Varone V, Picardi M, Baldi C, Memoli D, Ciancia G, Selleri C, De Rosa G, Vetrani A, Zeppa P: CD10, BCL6 and MUM1 expression in diffuse large B-cell lymphoma on FNA samples. Cancer Cytopathol 2015; 124:135-143.

32 Hans CP, Weisenburger DD, Greiner TC, et al: Confirmation of the molecular classification of diffuse large B-cell lymphoma by immunohistochemistry using tissue microarray. N Engl J Med 2002;103:275-282.

33 Scott DW, Wright GW, Williams PM, Lih CJ, Walsh W, Jaffe ES, Rosenwald A, Campo E, Chan WC, Connors JM, Smeland EB, Mottok A, Braziel RM, Ott G, Delabie J, Tubbs RR, Cook JR, Weisenburger DD, Greiner TC, Glinsmann-Gibson BJ, Fu K, Staudt LM, et al: Determining cell-of-origin subtypes of diffuse large B-cell lymphoma using gene expression in formalin-fixed paraffin-embedded tissue. Blood 2014;123:1214-1217.
34 Visco C, Li Y, Xu-Monette ZY, Miranda RN, Green TM, Li Y, Tzankov A, Wen W, Liu WM, Kahl BS, d'Amore ES, Montes-Moreno S, Dybkær K, Chiu A, Tam W, Orazi A, Zu Y, Bhagat G, Winter JN, Wang HY, O'Neill S, Dunphy CH, Hsi ED, Zhao XF, Go RS, Choi WW, Zhou F: Comprehensive gene expression profiling and immunohistochemical studies support application of immunophenotypic algorithm for molecular subtype classification in diffuse large B cell lymphoma: a report from the international DLBCL Rituximab-CHOP Consortium Program Study. Leukemia 2012;26:2103-2113.

35 Rosario-Quinones F, Strauchen JA, Salem F: Anaplastic large cell lymphoma masquerading as classical Hodgkin lymphoma on fine needle aspiration. Diagn Cytopathol 2015;43: 916-919.

36 Chhabra S, Verma R, Jain P, Tayal M, Singh J, Sen R: Anaplastic large cell lymphoma: a cytological masquerade. Am J Med Case Rep 2015;3:247-249.

- 37 EuroFlow: resetting leukemia and lymphoma immunophenotyping - basis for companion diagnostics and personalized medicine (editorial). Leukemia 2012;26:1899-1907. 